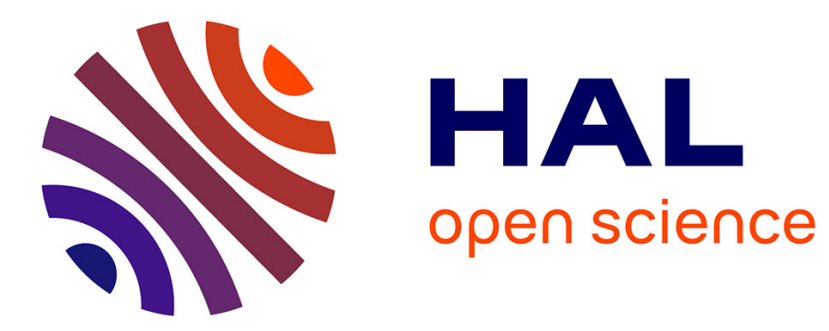

\title{
Negotiating Social Identities on an Eastern Maroon Radio Show
}

Bettina M Migge

\section{To cite this version:}

Bettina M Migge. Negotiating Social Identities on an Eastern Maroon Radio Show. Journal of Pragmatics, 2011, 43 (6), pp.1495-1511. halshs-00674702

\section{HAL Id: halshs-00674702 \\ https://shs.hal.science/halshs-00674702}

Submitted on 27 Feb 2012

HAL is a multi-disciplinary open access archive for the deposit and dissemination of scientific research documents, whether they are published or not. The documents may come from teaching and research institutions in France or abroad, or from public or private research centers.
L'archive ouverte pluridisciplinaire HAL, est destinée au dépôt et à la diffusion de documents scientifiques de niveau recherche, publiés ou non, émanant des établissements d'enseignement et de recherche français ou étrangers, des laboratoires publics ou privés. 


\title{
Negotiating Social Identities on an Eastern Maroon Radio Show
}

\author{
Bettina Migge $^{*}$ \\ School of Irish, Celtic Studies, Irish Folklore \& Linguistics, University College Dublin, Newman \\ Building A 203, Belfield Campus, Dublin 4, Ireland
}

\begin{abstract}
In recent years, Pidgin and Creole languages have made significant inroads into the public domain of the countries where they are spoken. The media, and the radio broadcasting sector in particular, are the areas in which they figure most prominently. Extension of their use has brought about linguistic changes (Garrett, 2000). This paper explores such changes in relation to the Eastern Maroon radio program Loweman Pansu broadcasted in French Guiana. It investigates whether the program assimilates established norms and practices of programs run in European languages or introduces innovative ones based on local practices. Analysis suggests that the program's makeup and linguistic practices contribute to the emergence of an alternative social space that is distinctly Eastern Maroon in character but integrates properties that are linked to the urban context. This contributes to the construction of a modern urban Maroon identity that transcends traditional ethnic and national borders.
\end{abstract}

Keywords: Radio discourse, Creoles of Suriname, Identities, Changing discourse practices

\section{Introduction}

In most post-colonial societies the radio and television broadcasting sector continues to be dominated by European languages (Devonish, 1986:92-93). In part, this is because there was usually already a tradition of using the European language for these purposes during colonial times and because at least some of these regions are highly multilingual. In the latter cases, societies often opt for the former colonial language instead of choosing one of the local languages because it is viewed as more neutral and its continued use financially less burdensome (Migge and Léglise, 2007:307-310). However, even if the members of a society/country share one or more local languages, the European language tends to have a privileged place in this domain. This suggests that dominant attitudes around local languages may be playing an important role in maintaining and sustaining European languages as the primary media in the broadcasting sector.

In many regions, local languages are often believed to be unfit or unsuitable for use in the public formal domain, which is dominated by European Standard languages. In the minds of many, including many of their speakers, especially those who also have competence in European languages, they are linguistically deficient, lack social prestige and are frequently denied language status being negatively identified as dialects or patois (Calvet, 1974). Local languages therefore tend to be largely restricted to informal and private interactions. This language hierarchy has the negative effect that, depending on overall levels of education, major sections of the

\footnotetext{
${ }^{*}$ Tel.: +35 317168477, fax: +35 317161117

E-mail address: bettinamigge@ucd.ie
} 
population are not able to consume radio and television broadcasts and/or lack motivation to engage with them. They are also not able to make their own voices heard on and through these media so that the broadcasting sector effectively becomes the domain of activity of the privileged sections of society.

However, this situation has been changing in recent years. On the one hand, attitudes towards local languages have, at least in part, been changing. Languages that were previously firmly excluded from the public domain, such as Kwéyòl in St. Lucia (Garrett, 2000:79), are increasingly becoming acceptable in at least some public settings such as election campaigns, informal education, the performing arts (Carrington, 2001) due to a greater emphasis on diversity and the assertion of local identities following political independence of post-colonial states. On the other hand, due to competition among radio stations for audiences, stations are constantly exploring new ways to make their programs attractive to new groups of listeners. Many stations have therefore integrated public-opinion type features such as call-in programs and interviews with 'the man on the street' that give members of the public the opportunity to express their views using linguistic practices that they feel comfortable with. Shields-Brodber (1992), for instance, shows how callers and hosts to Jamaican call-in shows regularly switch between English and Jamaican Creole when talking about all kinds of issues. In other settings, radio stations have integrated programs entirely carried out in a local language. Garrett (2000) informs us that all three of St. Lucia's radio stations have successively added new programs presented in Kwéyòl and that in 2000 broadcasting in Kwéyòl was available for more than eight hours a day.

One aspect that has so far received little attention in research is how instrumentalization of languages previously excluded from the public domain affects their use. Garrett (2000:78-89) argues that in the case of Kwéyòl in St. Lucia its use in radiobroadcasts has led to the emergence of a new variety, which he refers to as 'high Kwéyòl'. This variety bears much structural and stylistic influence rather than direct lexical borrowings from English and to a lesser extent from French. While it enjoys support and prestige, and is widely used in domains that were formerly exclusively associated with European languages, for instance public speeches by government officials, it is not always intelligible to speakers with little or no competence in the European Standard languages. Broadcasts using high Kwéyòl are therefore less popular than those employing everyday Kwéyòl because the latter are more closely aligned with the life-worlds of most St. Lucians (Garrett, 2007).

Local radio stations in both Suriname and French Guiana have in recent years also successively integrated new programs carried out in local languages to attract members of local communities to their radio station. In both countries, there are currently several programs that employ the Creoles of Suriname, specifically varieties of Sranan Tongo and varieties of the Eastern Maroon Creoles or Nenge(e). ${ }^{1}$ In Suriname, the radio station Konyeba broadcasts all-day and nearly exclusively in varieties of the Eastern Maroon Creole.

In this paper I explore the linguistic practices on one of these radio programs, the program called Loweman $\mathrm{Pa}(a) n s u$ which is broadcast in western French Guiana.

\footnotetext{
${ }^{1}$ Naming practices for the Creoles of Suriname are quite heterogeneous. In French Guiana, nonMaroons often refer to all of them using the term Takitaki or a positive auto-denomination, Businenge Tongo, that was introduced by Aluku Maroons in French Guiana (Price \& Price 2003). Among themselves, speakers either use ethnic terms such as Aluku, Ndyuka and Pamaka or the generalising term Nenge $(e)$ in order to refer to the Creoles traditionally spoken in eastern Suriname and western French Guiana. For more detail on the naming issue in French Guiana, see Léglise \& Migge (2006).
} 
Specifically, I investigate whether the program essentially assimilates European norms or goes beyond such established norms to introduce innovative practices and how these practices contribute to the construction of local social identities. The data for the analysis come from recordings and observation of the program over a number of years and a discussion with one of the broadcasters and regular listeners. Analysis suggests that the overall makeup of the program, including its linguistic practices, contribute to the emergence of an alternative social space. This space has a distinctly Eastern Maroon character, but integrates properties and practices such as code-mixing that belong to the urban context and to informal interactions. This contributes to the construction of a modern urban identity that transcends traditional ethnic boundaries.

In this paper, identity is broadly defined as a person's sense of belonging to a specific social group, society or place. It is widely recognized that people generally claim membership in multiple groups due to their involvement in different social settings and consequently performance of different social roles. While any social practice enters into the process of social identity construction, it has been widely acknowledged that people actively draw on discourse and language practices when constructing their social alignments (Fairclough, 1992; Bauman and Briggs, 1990). That is, through a process of iconization specific languages, ways of using a language or linguistic properties become indexes of social groups or identities with which they are associated (Irvine and Gal, 2000:37).

The paper is structured as follows: Part two briefly discusses the social context. Part three discusses the makeup of the radio program. Part four looks at the linguistic and interactional practices in a discussion program. The final part summarizes the findings and discusses their implications.

\section{The social context}

The coastal area of western French Guiana used to be mainly populated by French Guianese Creoles and a much smaller Amerindian population (Kali'na) as well as some Maroon families (Aluku, Ndyuka, Pamaka, Saamaka) that had come to St. Laurent (du Maroni) mostly since the 1960s. Until about the middle of the last century the town of St. Laurent was also the center of a French indentured labour colony, le bagne. The population was engaged in subsistence farming, some small-scale goldmining or found employment first through the bagne and later through the local French administration when French Guiana became a départment d'outre-mer in 1946. The two main towns in western French Guiana, St. Laurent and Mana, were quiet small towns. Their inhabitants also frequently visited the bustling Surinamese border-town of Albina which is only about a 10 minute boat ride across the Maroni river from St. Laurent.

However, the situation changed drastically in the 1980s during the civil war in Suriname. St. Laurent, Mana and the whole of western French Guiana suddenly became the home of a great number of Maroon and Amerindian refugees fleeing persecution and/or rapidly deteriorating living conditions. Most of the refugees originated from the Cotika, Commewijne, Galibi, and Sipaliwini region of Suriname. ${ }^{2}$ They were later joined by people from the upper and middle reaches of the Maroni River and the Tapanahoni River. Despite encouragement from the French government to return to Suriname, many of the refugees settled permanently in western French Guiana and in the towns of St. Laurent and Mana in particular. Since this initial

\footnotetext{
${ }^{2}$ The Sipaliwini district in Suriname includes most of the interior region of Suriname.
} 
'forced' displacement, migration to western French Guiana has continued to his day. Many of these migrants, who are mostly young people, come from smaller traditional villages and settlements in the interior of French Guiana and Suriname. They mostly come to western French Guiana 'in search of a better life', i.e. access to schools, healthcare, cash labor. This on-going migration has led to a rapid increase in the local population and subsequently also brought about a significant expansion of the local infrastructure such as roads, housing, schools, administrative services as well as commercial outlets. Both St. Laurent and Mana have much expanded in size and particularly St. Laurent is increasingly becoming an important regional center. ${ }^{3}$ While unemployment and dependency on social money remains high, the region is now offering a much wider range of services and employment opportunities.

Migration has also led to important social and linguistic changes. The French Guianese Creole population has been diminishing proportionally and in real numbers. Many of them are moving to eastern urban centers because they feel that their lifestyles are being threatened by the immigrants and in order to avail of what they consider to be better educational opportunities. Current estimates (Léglise, 2007) suggest that about $40 \%$ of the population in the West are of (Surinamese) Maroonorigin. In addition, many Amerindian populations have also come to permanently settle in and around St. Laurent and the rapid expansion of government services such as schools and administration has also brought a greater number of persons of European (French) origin to western French Guiana - the majority of teachers in French Guiana are still of European French or French Antillian origin (Léglise and Puren, 2005). However, most of them only stay for a few years. Finally, members of other national communities such as Haitians, Guyanese and Brazilians have also made St. Laurent their home.

The Surinamese Creoles play an important role in this new context. Members of the Maroon population are in the majority speakers of varieties of Nengee such as Aluku, Ndyuka and Pamaka (cf. Léglise, 2007). The Maroon population also includes an important number of Saamaka speakers; Saamaka and Nengee both descend from the varieties that developed on the plantations of Suriname, but they are not entirely mutually intelligible mostly due to lexical differences. In addition to Maroons, Amerindian populations also make frequent use of the Creoles of Suriname. They typically speak varieties of Sranan Tongo - traditionally associated with the urban areas of Suriname - either as a second language, an important community language (some Kali'na communities) or as the only/main community language (Arawak of Balaté). Finally, a sort of Sranan Tongo, locally often referred to by the name of Takitaki or Businenge Tongo, is increasingly being practiced as a second language by non-Maroons from diverse ethnic groups in the region (Léglise and Migge, 2006). Although Sranan Tongo is not fully mutually intelligible with the Maroon Creoles, most Maroons have some exposure and competence in it.

In terms of their official status, the situation is somewhat heterogeneous. In Suriname, Sranan Tongo is recognized as the country's national language. In recent years, it has made much headway towards being integrated into the public domain from which it used to be firmly excluded. It is now widely used in political campaigning, informal education, and service encounters in general. By contrast, the Maroon languages do not have official status in Suriname (Carlin, 2001) and are often

\footnotetext{
${ }^{3}$ Some smaller rural villages such as Apatou, Gran Santi on the Maroni River have also undergone rapid urbanization due to migration.
} 
subject to negative evaluations in the wider society though in recent years the situation has been improving.

In French Guiana, by contrast, the Maroon languages are referred to as "new languages of France' since 1999 and are likely to become 'local or regional languages of France' as defined in the European charter for regional and minority languages. While French continues to heavily dominate the public domain in multilingual French Guiana, the Creoles of Suriname, Sranan Tongo and Nengee or a koine referred to as Takitaki, are increasingly functioning as a lingua franca in the western part and a process of de-stigmatisation is under way. They can be heard in service encounters, some formal instruction has been integrated into some schools and they are used for some informal educational activities. However, despite their wider use, they continue to be locally viewed as the language of a specific (Buisnenge/Surinamien) ethnic group (cf. Léglise and Migge, 2006).

Due to their origin as runaway communities that openly defied colonial rule, Maroons see themselves as independent socio-political entities. Each Maroon community has its own government, socio-political structure, laws and land rights. Despite periodic disagreement about land rights, especially if the land has exploitable natural resources, and the jurisdiction of national law enforcement, France and Suriname, in principle, recognize the distinct status of these communities. ${ }^{4}$ The Maroon communities have therefore always also had a well-defined formal public sphere distinct from that of the national states and dedicated social and linguistic formal practices. The formal domain involves the performance of rituals and the holding of meetings (kuutu) about a wide range of issues concerning the community such as the organization of important social events like burials and end of mourning periods. A prominent aspect of the formal domain is the formal arbitration of disputes. The main speaker-participants in the formal domain are titled persons, kabiten 'village or lineage head', gaaman 'paramount chief' and (male) elders. Kuutus are carried out using a well-defined formal variety of Nengee referred to as lesipeki taki (Migge, 2004). It differs in several respects from formal practices in European languages and resembles practices reported for African societies. It is characterized by a variety of negative politeness practices. As these practices are also obligatory when dealing with delicate issues in general and when addressing socially important persons such as elders or titled persons, it is safe to assume that all members of the community are familiar with them and/or their main characteristics. However, speaking competence and to a lesser extent comprehension competence are highly variable. Lesipeki taki is most closely associated with (male) elders and titled persons, the leaders of these communities. While these practices may lead to making issues quite opaque, especially the highly controversial ones, their appropriate use is widely seen as assigning respectability to the user and importance to the issue.

Currently, there is a sizable number of young Maroons who have either spent all or most of their life in the coastal urban centres of French Guiana (and/or Suriname) and have increasingly less contact with the traditional village setting and traditional Maroon life-styles. Having received formal education and acquired competence in French (and/or Dutch), most of them consider themselves to be French (and/or Surinamese) while at the same time also seeing themselves as an integral part of the

\footnotetext{
${ }^{4}$ Note, however, that the relationship of the national states to the Maroon communities may be described as one of minimal tolerance as they do not actively engage in preserving these communities' distinctiveness in language and culture. In recent decades, the national governments have also at times disregarded and actively undermined the vitality of these communities (cf. Price, 2002; Price and Price, 2003: 71ff).
} 
social structure of their Maroon community. Both of these alignments are not without problems, however. Due to its history, traditional Maroon culture is closely linked to a rural subsistence life-style that traditionally assigns negative connotations to things and people urban, including urbanized Maroons. Even today, all socially, ritually and politically important practices and decisions are taken and have to be carried out in the traditional upriver villages. However, it is equally difficult for urban Maroons to fully align as Surinamese and particularly as French because both mainstream societies do not highly value Maroon cultures, to which they often assign notions of lack of sophistication and backwardness. As a result, young urbanized Maroons are in need of creating a positive social identity for themselves that integrates features from both these identities. The radio presents in many ways the perfect arena for this. The radio's technical nature projects an aura of modernity and urbanity, and it also provides for the possibility of reaching people across relatively great distances. Finally, by selecting a public arena traditionally dominated by European languages, the practices are being elevated, making them socially acceptable and respectable.

\section{The radio program Loweman Pansu}

The radio program Loweman Pansu was initiated in 2001 in St. Laurent du Maroni on the local radio station UDL (Union de la Défence des Libertées) which broadcasts during the week from $6 \mathrm{am}$ to $12 \mathrm{pm}$ and 24 hours during the weekend (http://www.udlguyane.com/). ${ }^{5}$ The program was initially only on the air two days a week for one hour in the afternoon. However, due to its popularity, its broadcasting time soon increased; in 2009 the program runs every day during the week from 6-8 pm. The program is partly modelled on the all day Surinamese (Eastern) Maroon station Konyeba. Loweman Pansu is currently run by two Ndyuka men - Basya Ayun and Basya Dyogiiboy - and two Kotika-Ndyuka women, Basya Klea and Basya Joanne. Basya Marlon is of Saamaka origin and only recently joined the program. All are in their 20s and 30s and grew up in the urban coastal areas of Suriname and French Guiana. Their work for the program is mostly done on a voluntary basis. Each evening at least two of them successively realize the program.

Loweman Pansu coexists with two other local radio programs in St. Laurent, namely Didier and Sten. The latter two programs are only broadcast for a few hours once or twice a week on Radio Reutemeger. They use the related urban Creole Sranan Tongo and target the wider Surinamese-Creole speaking population. Sten is essentially a religious program while Didier mostly focuses on popular music and local news. In contrast to these programs, Loweman Pansu's main target audience, as indicated by its name 'offspring of the runaways', are (Eastern) Maroons. However, others, such as local Amerindians also regularly tune into the program. Both socially and linguistically, the program clearly places itself within an (Eastern) Maroon tradition. People listen to both Didier and Loweman Pansu, but it appears that the latter is the more popular of the two because besides offering a good range of local music it also directly addresses Maroon's interests.

The overall format of the Loweman Pansu program resembles other broadcasts. It includes typical features such as advertising, announcement of upcoming events (leklama kamba), obituaries (tyali nyusu), birthday announcements (fuyali boto), news features (nyusu) and a discussion forum called yee na yu. Throughout the program

\footnotetext{
${ }^{5}$ The word pansu 'off spring' has a long medial vowel [paansu] but in local writing practices vowel length is not consistently represented; the same also applies to the name of the Surinamese station konyeba [konyeebaa] 'come listen please'.
} 
local and international popular music is played. Songs are used to delimit different parts of the program and different sections of a particular program feature. So for instance, one or two songs feature between advertising and the main discussion, but very often a song also features in the middle of the discussion program as a kind of pause. In these instances, the music is the main focus of the program. However, at other times such as during advertising the music is overlaid by the presenter's talk. Music is heard in the background and at times becomes louder, puncturing the talk. Throughout the program, the presenters also comment on the music being played as well as on the different music styles and singers or bands that feature in the program. It is fair to say that music is a central feature of the program; many of the listeners tune into Loweman Pansu specifically because of its music.

The unique aspects of the program include its content and presentational style. In this section I will discuss the content of the program. The content of the program deals squarely with the concerns of the urban (Eastern) Maroon population in western French Guiana, most particularly that of St. Laurent. For instance, Loweman Pansu frequently presents advertising for local events such as concerts and competitions. It also announces matters concerning citizens of Suriname only such as the visit of Surinamese ID card makers to Albina. Unlike French-speaking programs, Loweman Pansu also frequently advertises events taking place in Suriname. In Extract (1), for instance, the presenter is announcing a Surinamese Independence Day party in the eastern Surinamese town of Mongo in Suriname.

\section{Extract (1) Event Advertising}

lesipeki alikiman, PLB promotion e tyai wan gaan bigi mawina selefidansi anga 2004 'respectful listener, PLB promotion is organizing a very big independence day party with 2004' kon gi wi a ini dda Meongo konde. Aiyoo, selefidansi a yali ya o de a moo gaan bigi 'for us in the town of Meongo. Yes, this year's independence day party will be the biggest one' wan bika efu u luku lesipeki alikiman na fanafu 1975 Saanan de fu en seefi.

'because if we look at it, respectful listener, it's since 1975 that Suriname has been independent'

Dati wani taki a yali ya na 29 leisi kaba di den holi en, en ná wan taa

'that means, this year it's 29 times already that they've held it, and there isn't a better' peesi moo enke baala Romeo Bravo Stadion na dda Meongo konde en fanafu tu yuu 'place than the brother RB Stadium in Meongo and from two o'clock' mamanten lesipeki alikiman [p] da u e abi a ini a voorprokrama lesipeki alikiman 'in the afternoon, respectful listener, we will have in the preprogram, respectful listener,' da i abi uman pikin anga mannenge futubali [...] lesipeki alikiman a ini a taa pisi 'there is women's and men's football, respectful listener, in the other part' baka I abi salakibali naki gowtu pe Alibina paamisi Meongo taki a o soi en wan sani. 'you have Schlagball hitting gold where Albina promises Meongo that it'll show them something' Note: $[\mathrm{p}]=$ short pause

The fact that he is inviting listeners to attend a clearly Surinamese-oriented event that also takes place on Surinamese soil on a French radio station is quite interesting. It suggests that the program's target audience identifies with Surinamese concerns and has knowledge of the social background, including the event, its venue and the games to be played. This and other events of this nature are usually not advertised on Frenchspeaking radio programs. Contrary to official politics on both sides of the border which is at pains to emphasize the juridical differences between French Guiana and Suriname through policing, residency rights and tight visa regulations, the radio program essentially sets up or rather reinforces the existence of a transnational community of people who are at home and involved in the life of both countries. 
Advertising on Loweman Pansu also differs from that found on French radio programs in that it nearly exclusively focuses on local, community-based shops that cater mainly to Maroon needs. Moreover, the radio presenters create these advertisements on the spot based on a few specs from the shop owners, see Extract (2).

Extract (2) Kapsalon 'hair dresser's'

da u e dyombo go na a leklama kamba, lesipeki alikiman, en u de nownow na Destiny [p]

'Now we are jumping to advertising, respectful listener, and we are now at Destiny

lesipeki alikiman, Destiny kapsalon, lesipeki alikiman, anga ala boutique [...]

'respectful listener, Destiny hair dressers', respectful listener, with its boutique.'

Dati kai ondo fu sisa Lena, lesipeki alikiman, Destiny kapsalon na Charbonier konde

'It's managed by Ms Lena, respectful listener, Destiny hair dressers' at Charbonière,'

Rue de Sapotil nombu twalufu, lesipeki alikiman, i e si taki na wan extra kapsalon di

'12 Rue de Sapotil. Respectful listener, you see it's another hair dresser that'

opo a ini a pasi fu meke seeka gi den sama, a ini meke u taki a moi koosi te go doo

'opened in that street to beautify people. In there, you get everything from nice clothes'

falisi nangaa, moi uwii, wave uwii, ala den soutusoutu uwii san yu abi, dan a e meke

'to plastic nails, nice hair and nice curls. She can deal with all kinds of hair styles'

seeka gi i en a tanpu fantiwoutu na a pisi de. A e opo fu monde te anga sataa, lesipeki

'and she is responsible for the place. It opens from Monday to Saturday'

alikiman, aiti yuu fu te anga sigisi yuu bakadina, [...]

'respectful listener, from 8 o'clock until 6 in the afternoon.'

The advertisement in Extract (2) was presented with background music by the presenter Basya Kaago. The presentational style approximates that of commercially created advertisements but differs slightly each time it is presented. The shop being 'advertised' is located in the most well-established Maroon neighbourhood, La Charonière, and specifically caters to Maroon women's beautification styles and needs such as artificial hair extensions and waving etc.

Besides advertising, the topics of discussion are also strongly geared towards the needs and concerns of the local Maroon population. In the dedicated biweekly discussion program yee na yu the presenters, usually together with invited persons, broach a broad range of topics that are of current interest to community members. For instance, one discussion period was dedicated to explaining the structure of free health provision and another one discussed the relationship between the upriver and the downriver Maroon community, see below. Yet another program dealt with the problems that many Maroon children face when attending French schools.

Another important aspect of the program is that it plays music styles that appeal to the local Maroon population. Besides the wide range of music styles produced in Suriname and specific Maroon styles such as Aleke (cf. Bilby, 1999), Loweman Pansu also plays Reggae and other Caribbean and African music styles which generally do not figure at all or rarely on French-speaking radio programs. The program presenters also invite bands or singers and DJs to discuss their music with them. The bands that they invite are those engaged in locally popular music styles and in their songs address locally socially salient issues. It appears that they use such discussions to raise consciousness about certain issues such as Maroon history, Maroon's social obligations and their relationship to the police etc. A case in point is Extract (3). Here the presenter Basya Dyobiiboy is asking the singer Baa Silo to give details about his songs. 
Extract (3) discussion of music

Basya Dyogiiboy : [...] Baa Silo a de pe fi i booko en gi den sma a den osu. A mama Afrika, san wani taki dati? 'Baasilo explain this to the people at home. Mother Africa, what does that mean?'

Baa Silo : A mama Afrika, ala sama sabi kaba taki ala baaka man roots komoto fu

'Mother Africa, all black people already know that their roots are in Africa.'

Afrika winsi pe fu goontapu ya $i$ de, neen i e teli fu wan baaka man, $i$ sabi taki i roots

'No matter where in the world they are; when you are a black person, you know your roots are' na fu Afrika. Ma wel u man di kon fika a Marwina ya, wi abi a rutu fu Afrika ete [...] 'in Africa.. But we who've come to live here on the Maroni River, we still have African roots.' I si dus da te i e aliki a poku ya, da i e taki mi peemen wan style ini a businenge style. 'You see, when you listen to this music then you say I'm playing a kind of Maroon style' Den man be taki wan weti style de da mi e suku fu krier san u abi ya, a ini wi enke loweman pikin. [...] 'They said there's a European style, then I try to create something from what we have here in our runaway off-spring style.'

[music]

Basia Dyogiiboy : [...] Baa Silo te i luku da i si a sikififi mi liba. San wani taki dati ? 'Baa Silo, if you take a look, then you see it says 'my river'. What does that mean?'

Baa Silo : [...] omen lo e tan a ini den liba, ok ma nounou te i luku a libi fa a libi be e 'Lots of Maroon lineages are living on the rivers, but ok now when you compare how libi a fosi anga fa a libi e libi nounou da u be e subi gwe baka. Ma nounou te u dongo people used to live and how they live now, we used to always go back to the interior.' kon, u ná e gwe moo, da ala den gudu di u be abi a ini den liba... nounou efu u luku na 'Now when we come to the coast, we stay so that all the riches we used to have upriver,' Albina sikin wata da sineysi anga kuli, yampaneisi e meki osu kwala tee fu te ndyuka 'now when we look at the Albina shore, it's Chinese, Hindustanis and Indonesians who are' liba, fu te a Maipa. Nounou da a de taki dyonso a pisi tyubwa, a pisi doti di i gaan sama 'building houses all the way up to the Maroon areas. Soon your ancestors' land,' be abi de, te a yuu o doo bika di den man o go anda meke ndyuka liba anda. Wi o wani 'when they [Europeans] will come to make up the place, we will want to' go anda baka bika te a yuu o doo fi i go da $i$ abi fu lon suku pampila enke fa $i$ e lon 'go back there and then you will have to obtain papers the same way you have to run' suku pampila a Solan ya fi i mu go feni a eigi gaan sama sani fi $i$ anda.

'and search for them in St. Laurent now in order to avail of your ancestors' property.' I si dus, mi e taigi den loweman pikin, gaan wan anga pikin wan taki den mu e de na 'You see I'm telling all the off-spring of the runaways that they should be downriver bakaa na bilo ma meke den e go kiin den kampu fu den. Seeka taki te a yuu doo fu u 'in the European's world, but they should also maintain a residence upriver to make' no abi no wan problem.

'sure that when the time comes, we won't have any problems.'

In the first part of the interview, when asked to explain the meaning of mama Afrika, a term frequently used in his songs, the singer seizes the opportunity to create a positive self-identity for black people in general and Maroons in particular. He argues that black peoples all over the world are united by the fact that they are conscious about having their roots in Africa. Maroons are presented as being particularly close to their African roots and therefore their way of doing things, including music, are distinct from those of Europeans. He also asserts that he proudly engages with this distinctiveness with his music. In the second part, the singer urges Maroons to value and cherish the achievements of their ancestors, namely the lands that they won from the colonisers, and not to give them up lightly. He makes reference to the age-old fear of Maroons telling them to be vigilant at all times of non-Maroons and never to fully immerse themselves in European ways, but to always be ready to defend their rights 
(cf. Price 1983). He calls on (young urban) Maroons to remain firmly rooted in Maroon cultures while enjoying western life-styles.

This brief discussion of the content of the radio program Loweman Pansu demonstrates that it is clearly geared to an urban Maroon target audience and its concerns. It asserts the transnational nature of this community, its specific consumption needs, promotes community-based shops, and discusses practical issues that are of immediate concern to Maroons. It also promotes or rather asserts vital aspects of Maroon culture and Maroon perspectives of life while at the same time arguing that Maroon cultural ways are not incompatible with western or urban ways of life; this clearly departs from traditional western or Maroon notions of culture that see each other as polar opposites.

\section{Language practices and social identities on Loweman Pansu}

In this section I discuss the overall language policies and patterns of language use and the nature of stylistic practices on the radio program Loweman Pansu. Specifically, I investigate how these practices contribute to the construction of a unique urban Maroon identity.

\section{1. Patterns and policies of language use}

Linguistically, the program Loweman Pansu differs sharply from other radio programs on the station UDL or on other radio stations in Guyane in that it runs predominantly in Nengee. The official language of this overseas department, French, which is officially strongly enforced, is not used at all by the presenters and rarely by invited speakers. In the few cases that I have heard an invited speaker speak in French on the program, the presenters immediately translated their contributions into Nengee. This suggests that the organizers of the program assume that their listeners are not (always) fully competent in French and that they see the dissemination of knowledge (booko sani gi sama 'lit. break things down for people') as one of their main missions. In this sense then, Loweman Pansu defies or calls into question the dominant French position that the language of the public domain in France - even 7600 kilometres away from la metropole - is French and, more importantly, that the acquisition of knowledge is only possible through French. ${ }^{6}$

The practices in relation to the other varieties of the Surinamese Creoles differ from those around French. The most widely heard variety on the program is the Nengee variety Ndyuka because most of the presenters belong to the Ndyuka community; members of the smaller Eastern Maroon communities play a less important role so that Aluku and Pamaka varieties of Nengee figure much less frequently on the program overall. When people use these varieties, no special effort is made to facilitate comprehension probably because the three varieties are fully mutually intelligible. ${ }^{7}$ The overall dominance of Ndyuka is generally not perceived to be problematic in this context by the members of the smaller groups, but is essentially seen as 'normal' given the numerical dominance of the Ndyuka community and the

\footnotetext{
${ }^{6}$ This is, even today, often asserted by teachers in French Guiana and brought forward as a reason for opposing the wider use of local languages in education.

${ }^{7}$ Overall, the linguistic (and cultural differences) between the three Nengee varieties and Maroon communities are few (cf. Goury and Migge, 2003). However, they function as important markers of ethnic identities.
} 
fact that most of the presenters are members of the Ndyuka community. ${ }^{8}$ The fact that all three varieties are accepted on the program, as in everyday life, and that in discussions about cultural issues the presenters make an effort to 'check' details for the different groups such as by inviting representatives from each group is generally seen as showing sufficient respect for the cultural differences between them.

The presenters also apply similar practices in relation to other, less closely related and not fully mutually intelligible varieties of the Surinamese Creoles. So, for instance, when members of other ethnic groups such as members of Amerindian populations, persons from the coastal areas of Suriname, including Europeans, Saamaka Maroons or persons from other ethnic groups in French Guiana (Haitians, Europeans etc.) speak on the program, they are not obliged to approximate Nengee norms but may use the variety of the Creoles of Suriname that they are most familiar with. Their contributions are generally not translated into Nengee or specially commented on by the presenter. This implies that apart from granting people the freedom to express themselves in the language that they are most at ease in, it is also assumed that the listeners are able to understand other varieties of the Surinamese Creoles such as Sranan Tongo and Saamaka. This is noteworthy because intercomprehension is not always guaranteed, especially between Nengee and Saamaka but also in relation to heavily Dutch-influenced varieties of Sranan Tongo. It is also noteworthy that a person of Saamaka origin (Basya Marlon) recently joined the program. He uses both Saamaka and Nengee on the program. This kind of interMaroon collaboration further reinforces a pan-Maroon identity.

These language practices actively create or reinforce the notion of the existence of a linguistic and cultural bond among the speakers of Surinamese Creoles and assert a transnational pan-Maroon/ 'Surinamese' identity. Urban young Maroons tend to assert this kind of supra-ethnic identity because it is a way for them to distance themselves from the rural context in which ethnic identities such as Ndyuka, Aluku etc. play a paramount role (cf. Léglise and Migge, 2006). Association with the rural context is doubly problematic for Maroons. On the one hand, it is negatively connotated in the urban context and on the other, its leaders typically hold urban dwellers and their practices in low esteem. Assertion of an ethnic or pan-ethnic community can be seen as an act of dissent because it runs counter to French concepts of citizenship which deny the existence of ethnic groups on its territory and mandates identification around French republican cultural norms and values including the French language.

\section{2. Stylistic practices}

Stylistically, the program approximates a style sometimes referred to as lesipeki taki. This style of speaking is characterized by a range of negative politeness practices that are designed to avoid or mitigate open face threats and to ensure that interlocutors treat each other respectfully (Migge, 2004). It is mandatory in interactions that take place in the formal traditional Maroon public domain. So, for instance, unlike equivalent European-type programs, Loweman Pansu starts off by paying respect to the leaders of the community, including the two nation states on whose soil Eastern Maroons live. Giving respect to the authorities is a mandatory part in official meetings (kuutu) and when carrying out rituals (Extract 4). It functions to assert the traditional

\footnotetext{
${ }^{8}$ Historically, the relationship between the Ndyuka community and the smaller Maroon communities, Aluku and Pamaka, has been fraught with problems (cf. Hoogbergen, 1990; Léglise and Migge, 2006).
} 
social hierarchy and to situate ones' activities within an Eastern Maroon social framework.

\section{Extract (4) gi odi 'greeting'}

Basia Kaago: Lesipeki alikimaan, a ini a fosi pisi da u e bali wan switi sapaten go miti

'Respectful listener, as the first part, we wish the leaders of the community a pleasant'

den lesipeki kondee masa/ na so u e saka go na den ede kabiten te doo den kabiten kay

early evening. Then we move on to greet the leading village leaders, the village leaders

a den basya/ lolo towe doo na a hii lesipeki busikonde foluku/ wan bun switi sapatin/

'and their assistants and we continue all the way to the whole respectful Maroon people. A very'

lespeki alikiman, a ini a libi makandaa/ da u o begin/

'pleasant early evening, respectful listener. In our time together, we'll start off'

na a fosi pisi/ da u e bali komoto a wataa mofu/ da u e subi salla

"with the first part. We are calling from the shore (town), then we go upriver

te kai a dipi wataa, abaa go a faansi anga a doisi a ini wooko makandi

until we reach the deep water (traditional villages) cross to France and Suriname in our

time together'

Note: /: short intervals or pauses that puncture the turn

Another rather unexpected part is a disclaimer at the beginning of the program where the presenter apologizes for possible face-threats, Extract (5).

\section{Extract (5) gi piimisi a fesi 'advance excuse'}

[song plays]

en i á fegetee taki Soolan seefi de a ini wan pisi fu wi lobi goontapu [p]

'and do not forget that St. Laurent itself is in one corner of our beloved world'

son leisi te sani e go bun da i e si enke ná a ini a goontapu ya i de moo [p]

'sometimes when things go well it appears as if you're not in this world any more'

Ma terwel a ini a goontapu ya $i$ de ete [p]

'but in fact you are still in this world'

Ala sani di a programma tya kon a fesi a abi wan foutu, u e gi den alikiman piimisi

'all the things that the program presents have a mistake, we're apologizing to listeners'

bika sabi no de a yonkuu, sabi no de a gaandi [p]

'because young people lack knowledge, elders lack knowledge'

The advance apology in Extract (5) closely resembles the one typically heard at the beginning of all kinds of official meetings in the traditional villages. It explains that actions, or rather speech, that may appear to be offensive in the event to follow are likely to be due to people's lack of knowledge and experience rather than to ill-will. It emphasizes that people should assume a humble demeanour and avoid overreacting.

Another important indicator that presenters target respect speech is the fact that people on the program are usually addressed and referred to using a function title or a traditional courtesy title. For instance, the presenters are always referred to and addressed by visitors and by each other using the function title Basya (6b) which traditionally refers to an assistant in general and the assistant of the village head (kabiten) or paramount chief (gaaman) in particular. Community leaders are either referred to by a function title such as kabiten or by the courtesy title $d d a$ or by both (6a). Both of these may be used together with the person's name or without it. Callers or non-titled persons are generally addressed or referred to by the age/status appropriate courtesy titles, e.g. (6c-d) (Migge 2001). The use of these titles is crucial as it indicates people's positional identities or position within Maroon society. It constitutes a formal type relationship between among presenter and between 
presenters and invitees (or callers), and conveys interlocutors' respect for each other. These titles are also used to speak respectfully of locations and activities, including the persons associated with them (6e).

(6) a. Kabiten dda Anousa fu Charbonière 'the village head elder A. of Charbonière'

b. Basya Ayeni 'assistant Ayeni'

c. baala Abai, Baa Silio 'Mr Abai, Mr Silio'

d. sisa Lena 'Ms Lena'

e. dda Soolan konde 'respectful town of St. Laurent (lit. elder St. Laurent)'

However, there are a number of differences between the practices used on the air and those employed in the traditional context. One of the features relates to lexical choices. Traditionally, in formal contexts, the use of lexical items from other languages, especially Sranan Tongo, is considered to indicate a lack of proper alignment with the Eastern Maroon community and its values. On Loweman Pansu, however, presenters and other Maroon speaker-participants (invitees) clearly target Nengee items, but at the same time, they also make much more pervasive use of lexical items from other languages, such as Sranan Tongo, Dutch, English and French, than would be acceptable in formal settings. For example, the presenters frequently use the Sranan Tongo preposition nanga, the negation marker no and the modality marker kan interchangeably with their Nengee equivalents. They also make frequent use of Dutch expressions such as fermatie 'band', musik, faak 'often', belangrijk 'important', programma 'program', werkelijg 'truly', kulturu 'culture', en 'and', and a few English terms such as crew. Code-mixing is more common in more 'relaxed' parts of the program such as advertising, birthday announcements and discussions about music, but they are also found in other parts such as the discussion part. Codemixing on Loweman Pansu is (no longer) evaluated negatively; when the program first started to broadcast, especially middle-aged and elders complained about inappropriate language use.

Code-mixing on Loweman Paansu is clearly reminiscent of young men's peergroup speech and serves similar functions (cf. Migge, 2007). ${ }^{9}$ It displays the presenters' language skills and conveys the presenters' and the program's association with the urban context as well as their partial distancing from traditional rural conceptions of 'pure' Maroon-ness. However, code-mixing on Loweman Pansu is overall much less pervasive than in young male peer-group encounters as presenters make a concerted effort to display their alignment with an Eastern Maroon identity. Moreover, code-mixing on Loweman Pansu takes place between respect speech and Sranan Tongo, Dutch etc. while in young men's peer-group speech, it involves kowonu taki 'everyday Nengee' and other languages

In the traditional context, taboo topics and controversial issues are not addressed directly, but are discussed using polite place holders such as special lexical items (lesipeki mofu) and elaborate figures of speech (nongo). Both features, but particularly nongo, are not widely used on Loweman Pansu; polite lexical forms are used but in a somewhat less consistent manner. For instance, during a discussion about upriver marriage practices, both the presenter (B) and the (downriver) kabiten (K) speak in a direct manner about the issue. In Extract (7) they openly talk about taboo topics such

\footnotetext{
${ }^{9}$ Code-mixing practices are closely associated with young male peer-group behaviour. It carries negative connotations for (young) women; they make less frequent use of it and are more likely to engage in code-switching, particularly with European languages (Migge, 2007; Migge and Léglise, in preparation).
} 
as stealing (line 3) going out and pregnancy (line 7) and mostly do not make use of any special respectful lexical items or figures of speech to mitigate the potential facethreat. ${ }^{10}$ Note, however, that the kabiten uses the polite expression a si a sama kaba 'lit. he's already seen the person' to express that he has had sexual relations with the women.

\section{Extract (7) \\ 1 B: en kon u takifosil 'and come let's say' \\ 2 ah $I$ abi wan man di $e \quad d u$ ogiil you have one man REL PROG do evil 'you have a man who does bad things' \\ 3 a man a ogiiman, $a$ e fufuu $e$ du omen sani DET man COP evilman he PROG steal PROG do many thing anga sama, aii, with people yes 'the guy is a bad guy, he steals and does lots of bad things with people, \\ 4 ma wi a opu, so wan man, $i$ be $e$ gi en uman? but we LOC upriver so one man you PAST PROGgive him woman so we as upriver people, such a guy would you give him a woman in marriage?'}

$5 \mathrm{~K}$ : we na bee be e gi en uman ma na a dda akisi sama gi en

'Well, it's the family/linage that gives the woman but the elder asks for her.'

6 B: $m h m m$

[...]

$7 \mathrm{~K}$ : ma we efu a go waka anga wan sama pikin, neen a de but well if he go walk with one person child then she COP anga bee, with belly 'but if he goes out with someone's child, and then she is pregnant'

$8 d a$ a abi a bee di a si a sama kaba, den then it have DET belly REL he see DET person already they tapu wan se ain, a tapu wan se ain. close one side eye it close one side eye 'then she is pregnant since she's already had sexual relations with the person, they close one eye, i.e. just let it happen.'

Presenters of Loweman Pansu tend to use more overt ways of conveying respect than those typical of traditional settings. For instance, throughout the program the presenters juxtapose the adjective lesipeki 'respectful' to the word alikiman 'listener' as in lesipeki alikiman 'respect listener' or to invitees lesipeki kabiten 'respectful leader' when addressing the audience. This strategy is not found in the traditional context. Here speakers do not (must not) overtly address listeners including other speaker-participants at all. Speakers may only refer to others present and to what they say. Respect for the audience including the speaker-participants is encoded by other

\footnotetext{
${ }^{10}$ An anonymous reviewer suggested that the hypothetical or conditional nature of the question functions to deflect a possible face threat. In my experience, this only affects speech design to a small degree. Reference to a specific person requires the greatest amount of face-saving strategies or deflection strategies, e.g. use of parables. However, even in the case of hypothetical contexts mention of taboo topics is difficult and requires various sorts of veiling (e.g. special vocabulary and an apology) to deflect the face threat, especially in the case of public contexts that include elders as listeners.
} 
strategies such as avoidance of direct (combative) address and veiled reference to taboo issues.

Respect-implying terms are also frequently used when referring to people and places in radio talk. Lesipeki is frequently juxtaposed to terms referring to groups of people (e.g hii lesipeki busikonde foluku 'whole respectful Maroon people') and to important people within the community, e.g. lesipeki kondee masaa 'respectful head of the community' (Extract 4). Respect for places (or their communities) is expressed by combining the place names with the high status courtesy titles, e.g. dda Soolan konde 'the town of St. Laurent du Maroni'. This use of lesipeki as a respect or negative politenss-indicating modifier is not really found in the traditional context and the use of courtesy titles to convey respect for places is much less commonly used in traditional respect speech.

Another overt strategy of showing respect is the use of apologies prior to expressing something in a transparent or direct manner, including calling out someone's name. Take Extract (8), for instance. The presenter tries to find out from one of the invitees how disputes are arbitrated between Saamaka living outside of the traditional territory. In order to raise the issue, he gives an example involving the word ongooku 'disaster'. To mitigate the possible face threat that may be caused by invoking a negative issue or using a negative word, he inserts an apology in line 2 (piimisi fu taki) - in other instances the apology precedes the taboo issue or word.

\section{Extract (8)}

1 B: efu $i$ luku wi na Saamaka anda, te a kai wan ongoku,
if you look us LOC Saamaka there when it fall a disaster
'if you look at us in Saamaka, when bad thing happens'
te $i$ taki ongooku, piimisi fu taki, anga a taa baala
when you say disaster excuse for say with DET other brother
'when you say bad thing, excuse me for saying this, when two people'
sa go a wan peesi. Da wan ongooku miti I anga en
may go LOC one place then one disaster meet you with him
'may go somewhere else [outside of Saamaka]. A bad thing happens between'
fa $u$ kuutu so wan kutu
how we arbitrate so one issue?
'them, how do we arbitrate this kind of issue?'

In the traditional context, such apologies are also used, however, to a much lesser degree because negative actions and their participants are typically presented in a much more opaque manner using parables and metaphors.

Another aspect concerns the use of direct questions. In the traditional context, direct interrogative clauses are directed at children when wrong-doing is suspected. They are considered to be face-threatening acts because they put the questioner and questionee in a hierarchical relationship that is not felt to be appropriate among adults. In formal discussions, people do not engage in a question-answer format at all, but essentially narrate to each other their points of view about the issue at hand using a range of rhetorical devices such as parables, sayings and metaphors. This continues until the parties involved agree on a particular version of the issue. This is in stark contrast to what happens during discussions on the air. Here, radio presenters try to make issues explicit and thus put pointed questions of the sort shown in lines (2-3) in Extract (9) to invited speakers (cf. also Extract 8, line 4). In Extract (9), the presenter 
asks the kabiten to give an assessment of the relationship between downriver and upriver leaders.

Extract (9)

1 B: [...] he, he kabiten dda Anusa efu i luku na a libi fu na opu, 'ehm kabiten Anusa if you look at life ,in the traditional upriver villages'

$2 \quad i$ abi den kabiten fu u a Ndyuka anda anga den kabiten fu u na bakaa ya dis se 'you have the upriver village/lineage heads and those serving on the coast here'

3 fa i e si a wooko fu den kabiten fu bilo dis se anga den kabiten fu a opu anda? 'how do you judge the work of the upriver and the downriver kabiten?'

$4 \mathrm{~K}:$ We papa, we so wan soutu fasil

'Well elder, in that way'

$5 \quad$ i si da a fesikeli bigil

'you see, the responsibility is high'

6 bika saide te wan sani e pasa a ná fu den paandasi anda

'because why, when something happens it's not only the responsibility of the villages'

Invited speakers respond to them as best as they can, but often in fact give an evasive answer as in (9, lines 4-6) because they do not feel entirely at ease in such contexts. First, direct questions are felt to be intrusive because they force the person to go along with the agenda of the interviewer. Second, in the traditional context issues are generally discussed with reference to specific cases or problems and not in general. Third, as one kabiten points out in Extract (10), there is no tradition of talking about issues in this pointed, 'school-type' manner, i.e. using questions and answer formats.

Extract (10)

K: Ala den sama mi e gi paadon, enke fa Basya Ayen anga Basya Kago anga a taa 'I apologize to everyone in the same way that Assistants Ayen, Kago and the' Basia be e begi paadon kaba/ da u e begi piimisi/ a ini den wowtu di u sa kon 'other one have apologized for already, we ask for forgiveness for the words that' gebroiki a radio/ bika ná sabi enke wan sani di u teki sikoo bangi f'en ne en u 'we use on the radio because it's not knowledge that we've learned at school,' kon sidon $f u$ 'that we've come to talk about.'

Another feature of radio talk that diverges from traditional respect speech is the use of piki-taki. Piki-taki is the skilful interaction between a speaker (takiman- TM) and a ritual responder (pikiman- PM). Essentially, the speaker punctures their speech with brief pauses and the pikiman inserts short responses from a well-defined set of possible responses into these intervals, see Extract (11) from a traditional kuutu. Some of the pikiman's responses function as assessments (lines $4,6,10,16$ ) in that they "operate on the particulars of a current unit" (Goodwin 1986: 201), i.e. they respond to what the speaker is saying. Others, by contrast, function as continuers (lines 2, 8, 12,14 ) in that they "treat a unit of talk as part of a larger series of units" (Goodwin 1986: 213). Both kinds of units occur in the same slot in traditional events and some of them such as na so and a so a de may function as either an assessment or as a continuer. Piki-taki gives formal interactions a dialogic character. It places the speaker at the centre of attention and shields them from the comments of the other 
participants; it gives the speaker space to develop his own argument (Migge, 2004:296).

Extract (11)

1 TM: Te u be meki abspraki taki tya en kon baka.=

'If we had agreed that they bring them back'

2 PM: $=\mathrm{Mm}=$

3 TM: =I be sa seni kaa mi Tii Mbaaka kon mishaandi?=

You could send for me to verbally abuse me? (..)

4 All: =Kweti, $k w e t i$, no no=

'not at all, no no'

5 PM: =Begi, papa begi te u án sabi fa fu begi [moo. (.)

'we asked for forgivenness as much as we could

6 PM:

7 TM: =bika a sani den e kali $\underline{i \text { sama}}=$

$[\mathrm{Mmm} !=$

8 PM: $=N a$ [so 'that's it'

9 TM: [I ná e si go ne en ati.(.)

10 PM: Kwetikweti (0.4)

'you cannot look into their hearts

'not at all'

11 TM: Da meki wan sama waka kon na yu sama= 'then make someone come up to your people'

12 PM: $=$ Na $s o=$ 'that's it'

13 TM: =Da a naki en wan pisi tiki gwo, da i o si sama, san den e kali sama anga sama famii $=$

'then he hits him with a stick then you'll see who's part of their family'

14 PM: $=N a$ s[o 'that's it'

15 TM: [Da na ape i o si san na famii, san na famii (.)

'It's there that you'll see what it means being family'

16 PM: Na so a de papa 'That's the way it is, elder.'

Note: underlining marks emphasis

The full piki-taki style cannot be easily realized during all parts of the broadcast because for at least part of the time only one person, the radio presenter, is present. However, the speaker can allude to it by recreating its overall rhythm. The presenters achieve this by frequently though not consistently puncturing their speech with brief pauses (e.g. Extract 4). When the presenters engage in the piki-taki style, serving as pikiman during discussion pieces with invitees or callers, their performance diverges from traditional practices. As shown in Extract (12), for instance, the presenter only provides piki in a somewhat irregular manner. During some parts of the kabiten's speech (e.g. lines 1-4 and 16-18), the presenter inserts no piki into the intervals created by the speaker. In other parts (e.g. lines 5-15) he does insert a piki unit, but this unit $(\mathrm{mhmm})$ is more like a vocalization than a real piki. This kind of unit is rarely if ever used in formal settings as it is characteristic of conversational interactions. Typical piki phrases are na so, a so a de, iyaa papa etc. (cf. Migge, 2004). Moreover, all his piki's seems to function as continuers because they do not respond in a meaningful way to the preceding unit produced by the current speaker; they simply display the presenters understanding "that an extended turn at talk is in progress but not yet complete, while simultaneously collaborating in the achievement of that multiunit utterance by passing the opportunity to either (a) produce a more extended turn of their own or (b) initiate repair on the talk just heard." (Goodwin 1986: 207). Finally, there appears to be a greater amount of overlap between between $\mathrm{mhmm}$ and the 
speaker's units than would be deemed acceptable in traditional formal events. In traditional settings this kind of piki-taki would not be considered permissible and seen as endangering the takiman's turn or talk.

\section{Extract (12)}

$1 \quad \mathrm{~K}$ : We papa, we so wan soutu fasi (.)

'Well elder, well in this way

$2 \quad$ i si da a fesikeli bigi (.)

'you see the responsibility is heavy'

3 bika saide (.)

'because why'

4 te wan sani e pasa a ná fu den paandasi [anda

'when something happens, it is not only about those villages'

5 B:

$[\mathrm{mhmm}()$.

6 K: da na mofu e paa[ti

'message are disseminated'

7 B: $\quad[\mathrm{mhmm}=$

$8 \mathrm{~K}:=$ da te mofu paati kaba, da ala wi e kon [miti (.)

'once the news has been disseminated, then all of us come together'

9 B:

[mhmm. Na so a de 'yes, that's the way it is'

$10 \mathrm{~K}$ : A fuka di wi abi da u e sidon da u taki=

'we sit down and discuss the problem'

$11 \mathrm{~B}:=m h m m=$

$12 \mathrm{~K}$ : moi, san na a wooko di wi abi, da u wooko makandii=

'nice, we [on the Tapanahoni River] join forces to carry out our work'

$13 \mathrm{~B}:=\mathrm{mh}[\mathrm{mm}$

$14 \mathrm{~K}: \quad$ [ma a Maawina ya, da i e si en wan soutu fasi=

$15 \mathrm{~B}:=m h m m=$

'but here on the Maroni River, the situation is somewhat different'

$16 \mathrm{~K}:=b i k a$ a abi a fuka di e kai (.)

'because there are those problems that rise'

17 a kabiten sende mofu (.)

for which the downriver kabiten asks upriver dignitaries to gather'

somen man e kon somen man ná e kon=

'Some of them come others don't.'

$19 \mathrm{~B}:=m h m m$

Discussions with listeners suggest that this divergent piki-taki pattern is (no longer) considered a sign of lack of knowledge and verbal ability when used on the program. Instead it seems to have been reconceptualised as an urban piki-taki style suitable for non-traditional contexts such as the airwaves.

\section{Conclusion}

Radio programs that cater to the interests and needs of the majority of the local populations are a relatively new phenomenon in the multilingual Guiana plateau. Until very recently, all media operated in the official language of the country and focused on issues relevant for the wider society. This made radio programs rather inaccessible for the majority of the population whose competence in the official language (and culture) tends to be quite variable. Radio programs such as Loweman 
Pansu which is broadcast on the French Guianese radio station UDL have in recent years emerged specifically to fill this gap.

Analysis of the program's offerings and practices suggests that far from assimilating European models, the organizers of the program make a concerted effort to create their own unique style and identity that most closely resembles those of its primary target audience, namely (Eastern) Maroons living in the urban areas of (western) French Guiana. While the overall structure of the program is very similar to that of other programs in that it involves different kinds of features such as discussion features, call-in shows, interviews, music-focused features, and advertising, the topics treated and program delivery display a number of unique properties. Discussion topics, music-features and advertising focus primarily on the needs and interests of urban (Eastern) Maroons and to a lesser part other disenfranchised populations and also primarily promote commercial activities by community members. Where possible, the presenter, callers and invitees focus on emphasizing a positive selfimage of Maroons and Maroon culture to counter prevailing negative attitudes in the wider French Guianese society. At the same time, however, the presenters also distance themselves from a prototypical or traditional, rurally-based Maroon identity and seek to establish a separate urban Maroon identity.

Linguistically, a strong Maroon identity is constituted through a radical language policy on the program that promotes Nengee including other varieties of the Surinamese Creole complex as the only permissible languages and excludes or defines as foreign French, the official language of the country. This policy sets up the wider Surinamese-descent/lineage community and the Eastern Maroon community in particular as a separate (transnational) community that is distinct, independent and on a par with the wider French Guianese society. The language practices in relation to the use of Nengee on the program reinforce the program's and, by extension, the listeners' 'bi-cultural' identity. On the one hand, there is a clear alignment with Eastern Maroon cultural norms because the organizers target formal Eastern Maroon norms of language use typically employed in the traditional public domain. On the other hand, these norms are variably adapted. Essentially, some features that are considered old fashioned (piki-taki) and those that are seen as inhibiting understanding (traditional verbal indirectness properties to mitigate face-threats such as special figures of speech and the avoidance of direct questions) are replaced with less marked properties that are more appropriate for communication in the modern context. These changes are most likely part of a wider process of democratisation which also affects discourse patterns in other societies (cf. Fairclough, 1992). At this stage it is difficult to determine its origin, but it seems that social changes within the community coupled with formal western education and western-type interactional patterns in the urban domain may have triggered this process.

It appears that Loweman Pansu functions as social space where urban Maroons have the opportunity to express their own worldview using their own means of expression. This suggests that while instrumentalization of Nengee has or is leading to the emergence of a new formal domain, new language practices in the formal domain and a new formal language style, these innovations are not based on an exogenous paradigm or necessarily involve patterns of assimilation. In contrast to the St. Lucian case (Garrett, 2000, 2007), the new formal style is taking on board usage patterns typical of informal speech. It is more widely accessible to members of the community as it involves levelling of special linguistic properties that may cause problems of comprehension for people who are not familiar with rural formal practices. Instead of 
assimilating to either dominant, traditional Eastern Maroon norms or dominant western norms, the program is determined to define its own distinct profile.

\section{References}

Bauman, Richard, Briggs, Charles, 1990. Poetics and performance as critical perspectives on language and social life. Annual Review of Anthropology 19, 59-88.

Bilby, Kenneth, 1999. 'Roots explosion': Indigenization and cosmopolitanism in contemporary Surinamese popular music. Ethnomusicology 43(2), 256-296

Calvet, Louis-Jean, 1974. Linguistique et colonialisme: Petit traité de glottophagie. Payot, Paris.

Carlin, Eithne B, 2001. Of riches and rhetoric: Language in Suriname. In: Hoefte, R., Meel, P. (Eds.), Twentieth-Century Suriname: Continuities and Discontinuities in a New World Society. KITLV Press, Leiden, pp. 220-243.

Carrington, Lawrence, 2001. The status of creole in the Caribbean. In: Christie, P. (Ed.), Due Respect. Papers on English and English-related Creoles in the Caribbean in honour of Professor Robert LePage. University of the West Indies Press, Barbados, Jamaica, Trinidad and Tobago, pp. 24-36.

Devonish, Hubert, 1986. Language and Liberation: Creole Language Politics in the Caribbean. Karia Press, London.

Fairclough, Norman, 1992. Discourse and Social Change. Polity Press, Cambridge.

Garrett, Paul, 2007. "Say it like you see it": Radio broadcasting and the mass mediation of Creole nationshood in St. Lucia. Identities: Global Studies in Culture and Power 14, 135-160.

Garrett, Paul, 2000. 'High' Kwéyòl: The emergence of a formal creole register in St. Lucia. In: McWhorter, J. (Ed.), Language Change and Language Contact in Pidgins and Creoles. John Benjamins, Amsterdam, pp. 63-102.

Goodwin, Charles, 1986, Betweeen and within : Alternative Sequential treatments of continuers and assessments. Human Studies 9 (2/3), 205-217.

Goury, Laurence, Migge, Bettina, 2003. Grammaire du nengee: Introduction aux langues aluku, ndyuka et pamaka. Paris: Editions IRD.

Hoogbergen, Wim, 1990. The Boni Maroon Wars in Suriname. E. J. Briel, Leiden.

Irvine, Judith, Gal, Susan, 2000. Language ideology and linguistic differentiation. In: Kroskrity, P.V. (Ed.), Regimes of Language: Ideologies, Polities, and Identities. School of American Research Advanced Seminar Series, Santa Fe, pp. 35-83.

Léglise, Isabelle, 2007. Des langues, des domaines, des régions. Pratiques, variations, attitudes linguistiques en Guyane. In: ILéglise, I., Migge, B. (Eds.), Pratiques et représentations linguistiques en Guyane: regards croisés. IRD Editions, Paris, pp. 29-47.

Léglise, Isabelle, Migge, Bettina, 2006. Towards a comprehensive description of language varieties: A consideration of naming practices, ideologies and linguistic practices. Language in Society 35 (3), 313-339.

Léglise, Isabelle, Puren, Laurent, 2005. Usages et représentations linguistiques en milieu scolaire guyanais. Univers créoles 5, 67-90.

Le Page, Robert B. and Andrée Tabouret-Keller. 1985. Acts of Identity: Creolebased Approaches to Language and Ethnicity. Cambridge, U.K.: Cambridge University Press. 
Migge, Bettina, 2007. Codeswitching and social identities in the Eastern Maroon community of Suriname and French Guiana. Journal of Sociolinguistics 11(1), 53-72.

Migge, Bettina, 2004. The speech event kuutu in the Eastern Maroon community. In: Escure, G., Schwegler, A. (Eds.), Creoles, Contact and Language Change: Linguistic and Social Implications. John Benjamins, Amsterdam, pp. 285-306.

Migge, Bettina, 2001. Communicating gender in the Eastern Maroon Creole. In: Hellinger, M., Bussmann, H. (Eds.), Gender Across Languages. John Benjamins, Amsterdam, pp. 85-104.

Migge, Bettina, Léglise, Isabelle, (in prep.) Investigating Multilingual Communities. Language Choice and Use in a Creole Context. Cambridge University Press, Cambridge.

Migge, Bettina, Léglise, Isabelle, 2007. Language and colonialism. In: Hellinger, M., Pauwels, A. (Eds.), Handbook of Applied Linguistics. Mouton De Gruyter, Berlin, pp. 297-330.

Price, Richard, 2002. Maroons under assault in Suriname and French Guiana. Cultural Survival Quarterly 25(4), 38-45.

Price, Richard, 1983. First Time. The Historical Vision of an Afro-American People. John Hopkins University Press, Baltimore.

Price, Richard, Price, Sally, 2003. Les Marrons. Vents d'ailleurs, Châteauneuf-leRouge.

Shields-Brodber, Kathryn, 1992. Dynamism and assertiveness in the public voice: Turn-talking and code-switching in radio talk shows in Jamaica. Pragmatics 2, 487-504.

Bettina Migge received her $\mathrm{PhD}$ from the Ohio State University, Columbus, Ohio, USA and is currently Senior Lecturer in sociolinguistics at University College Dublin, Dublin, Ireland. From 1998-2004 she was Hochschulassistentin in Linguistics at the Institut für England- und Amerikastudien, at the Johann Wolfgang Goethe-Universität, Frankfurt am Main, Germany. Her main research and teaching interests are sociolinguistics and linguistic anthropology, contact linguistics and applied linguistics. She has published on contact linguistics (Creole genesis, code-switching), language and identity, language and migration and language and education. 